\title{
UCHODŹCY POLITYCZNI Z ITALII W OKRESIE PIERWSZEJ WOJNY DOMOWEJ I DYKTATURY L. KORNELIUSZA SULLI (88-79 PRZED CHR.)
}

\section{Tomasz Ładoń}

(1) http://orcid.org/0000-0003-0481-0484

Uniwersytet Humanistyczno-Przyrodniczy im. Jana Długosza w Częstochowie

\author{
ABSTRACT \\ POLITICAL REFUGEES FROM ITALY DURING THE FIRST CIVIL WAR \\ AND THE DICTATORSHIP OF L. CORNELIUS SULLA (88-79 BC)
}

During the First Civil War, political emigration occurred in Rome. The author of the paper distinguishes three stages of this emigration. The first concerns the period immediately after the outbreak of the First Civil War in 88 BC. At that time, a small group of refugees escaping Sullan repression reached Spain and Africa. The second stage involved the persecution that broke out in Rome after the victory of Cinna and Marius. In this case, emigration concerned a much wider population. First, refugees fled to the East to join Sulla, but they also sought out asylum in other parts of the Republic, for example in Spain or Africa. The third stage of emigration followed the victory of L. Cornelius Sulla in the First Civil War in Italy and the introduction of proscription (82 BC). Spain became the main destination for refugees, and their number was so great that they established their own center of power, organized armed forces, and resisted Sullan troops for several years.

In the paper, the author presents the reasons emigrants had for leaving Italy, the scale of the phenomenon, the main directions and circumstances of emigration, its nature as well as the actions undertaken by refugees to return to Italy.

Keywords: Marius, Sulla, emigration, refugees, Sertorius.

Słowa kluczowe: Mariusz, Sulla, emigracja, uchodźcy, Sertoriusz.

Eskalacja przemocy w życiu publicznym była jednym z głównych przejawów kryzysu Republiki Rzymskiej na przełomie II i I wieku1. Apogeum tego zjawiska nastąpiło w 88 roku, gdy wybuchła pierwsza wojna domowa między L. Korneliuszem

${ }^{1}$ Istnieje na ten temat bardzo obszerna literatura. Zob. np. A. Lin to tt, Violence in Republican Rome, Oxford 1968; A.N. Sherwin-White, Violence in Roman Politics, „The Journal of Roman Studies” 
Sullą a zwolennikami G. Mariusza i L. Korneliusza Cynny. W ciągu następnych blisko 10 lat przedstawiciele obydwóch stron stosowali wobec siebie represje, co powodowało, że zagrożeni śmiercią obywatele, nie widząc innego wyjścia, opuszczali Italię i szukali schronienia w różnych częściach imperium, stając się tym samym uchodźcami politycznymi.

Szukanie azylu poza Italią przez aktywnych uczestników życia publicznego w stolicy nie było zjawiskiem nowym w rzymskiej praktyce politycznej - prominentni Rzymianie od wieków udawali się na - często dobrowolne - wygnanie, którego powody mogły być bardzo różne ${ }^{2}$. W latach 80 . I wieku sytuacja uciekinierów była jednak inna. Za uchodźcę politycznego należało bowiem wówczas rozumieć obywatela rzymskiego, który na skutek uzasadnionej obawy o swoje życie, wynikającej z prześladowania lub represji politycznych, zbiegł z Rzymu - lub szerzej: z Italii - i skierował się na terytorium, na którym miał nadzieję znaleźć stosunkowo bezpieczne schronienie $^{3}$. Taki uchodźca nie był typowym dla praktyki rzymskiej wygnańcem, czyli nie udawał się na dobrowolne wygnanie (exilium), na którym bezpiecznie przebywał aż do ewentualnego odwołania przez senat. Był raczej uciekinierem czy też - stosując współczesną nomenklaturę - uchodźcą politycznym. Na takim obywatelu ciążył wyrok śmierci, ale wydany nie przez sąd, a przez organ sprawujący władzę (czyli przez senat, dyktatora lub zgromadzenie). Przed tym wyrokiem obywatel ani nie mógł się bronić, ani nie mógł się od niego odwołać. Również skala zjawiska była znacznie szersza. O ile we wcześniejszym okresie dziejów Republiki przypadki udawania się na wygnanie zdarzały się stosunkowo rzadko, o tyle w latach 80. I wieku szukanie schronienia poza Italią przed represjami ze strony władzy stało się powszechne.

Celem moich rozważań jest przeanalizowanie materiałów źródłowych pod kątem przymusowej emigracji politycznej z Italii w latach 80. I wieku, zbadanie przyczyn i kierunków podejmowanych wówczas ucieczek, określenie przekroju społecznego uciekinierów oraz próba ustalenia skali tego zjawiska.

W interesującym mnie okresie wyraźnie można wyodrębnić trzy fale uchodźców politycznych z Italii. Pierwsza, najskromniejsza, pojawiła się w 88 roku, wkrótce po zamachu stanu dokonanym przez L. Korneliusza Sullę, który zastosował represje wobec przywódców popularów. Chcąc uratować życie, musieli oni zbiec z Italii. Druga, znacznie silniejsza, nastąpiła po przejęciu władzy przez L. Korneliusza Cynnę i G. Mariusza w 87 roku i krwawych prześladowaniach, tym razem skierowanych przeciwko zwolennikom Sulli. Część z nich zdołała uratować życie dzięki ucieczce z Italii i rozproszeniu się po różnych częściach imperium. Trzecia fala uchodźców opuściła Italię po zwycięstwie Sulli w wojnie domowej z lat 83-82 i ogłoszeniu

1956, vol. 46, s. 1-9; E.S. Gruen, The Last Generation of the Roman Republic, Berkeley-Los AngelesLondon 1974, s. 405-448. Daty w tekście artykułu dotyczą czasów przed narodzeniem Chrystusa.

${ }^{2}$ G.P. Kelly, A History of Exile in the Roman Republic, Cambridge 2006, s. 20.

${ }_{3}^{3}$ Trzeba jednak zaznaczyć, że jeśli obywatel był ogłoszony wrogiem publicznym albo został wpisany na listę proskrypcyjną, to nigdzie nie mógł się czuć bezpieczny - Gordon Kelly (A History of Exile..., s. 3, przyp. 8) przywołuje przypadek Norbanusa (App., $B C$ 1, 91, 422), który w 82 r. schronił się na Rodos, gdzie Rzymianie tradycyjnie udawali się na wygnanie. Sulla rozkazał mieszkańcom wyspy go wydać, a Norbanus na wieść o tym popełnił samobójstwo. 
proskrypcji, wówczas ponownie duża liczba obywateli w obawie o życie uciekała z Rzymu, szukając schronienia poza jego granicami, przede wszystkim w Hiszpanii.

Materiał źródłowy, dzięki któremu można uzyskać dane na temat interesującego mnie zagadnienia, jest bardzo skromny, a do dyspozycji badacza pozostają wyłącznie źródła literackie, często fragmentaryczne i ogólnikowe. Najwięcej danych dostarczają Appian z Aleksandrii i Plutarch z Cheronei w żywotach Mariusza, Sulli i Sertoriusza. Wartość ich informacji pomniejsza fakt, że powielane są ze źródeł poprzedników, przez co często są zniekształcone, niejasne lub niepewne. Korzystając z ich przekazów, należy także pamiętać, że w dużym stopniu zostały one skażone propagandą, zwłaszcza sullańską ${ }^{4}$ W prowadzonych tu badaniach w mniejszym stopniu przydatne były fragmenty dzieł L. Anneusza Florusa, Wellejusza Paterkulusa, Eksuperancjusza i Orozjusza. Szczególnie ostrożnie należy podchodzić do informacji dwóch ostatnich autorów, którzy pisali z dużej perspektywy czasowej.

Autorzy antyczni nie postrzegali uchodźców politycznych jako osobnej grupy społecznej, o ucieczkach z Italii piszą więc najczęściej w kontekście wydarzeń politycznych. Czynią to albo przy relacjonowaniu istotnych faktów z życia wybitnych jednostek - wówczas poznajemy losy uciekinierów będących jednocześnie wpływowymi postaciami życia politycznego, na przykład Mariusza czy Krassusa albo niejako mimochodem, stwierdzając exodus z Rzymu wywołany konkretnymi działaniami władz. Nie zmienia to faktu, że dane zawarte w przekazach źródłowych pozwalają bliżej przyjrzeć się zarówno procederowi uchodźstwa politycznego z Rzymu, jak i motywom poszczególnych jednostek poszukujących schronienia poza granicami Italii.

Kwestia uchodźców politycznych z Italii w okresie pierwszej wojny domowej jako osobnego zjawiska charakterystycznego dla kryzysu Republiki Rzymskiej rzadko była przedmiotem badań uczonych ${ }^{5}$. Częściej pojawia się ona w biografiach wybitnych jednostek, ale wówczas taka przymusowa emigracja z Italii traktowana jest przez badaczy jako pewien etap w życiu bohatera i nie poddaje się jej analizie w szerszym kontekście ${ }^{6}$.

${ }^{4}$ E. Badian, Lucius Sulla: The Deadly Reformer, Sydney 1970, s. 4; E.S. Ramage, Sulla's Propaganda, „Klio” 1991, vol. 73, s. 93-121. Por. M. Barden Dowling, The Clemency of Sulla, „Historia” 2000, Bd. 49, H. 3, s. 303-340 (zwłaszcza s. 303-304, przyp. 2, gdzie dalsza literatura). O źródłach wykorzystanych przez Plutarcha i Appiana zob.: H. Peter, Die Quellen Plutarchs in den Biographieen der Römer, Halle 1865; E. G a b b a, Appiani Bellorum Civilium liber primus, Firenze 1958.

${ }^{5}$ Szerszej analizie zagadnienie to zostało poddane jedynie w kontekście Półwyspu Iberyjskiego. Zob. T. Ładoń, Hiszpania jako miejsce schronienia opozycji $w$ okresie pierwszej wojny domowej i dyktatury Lucjusza Korneliusza Sulli (88-79 p.n.e.) [w:] Rzym a Pótwysep Iberyjski. Różnorodność relacji od starożytności po wspótczesność, red. A. Grzelak-Krzymianowska, M.J. Woźniak, Łódź 2019, s. 213-232. Istnieją prace przekrojowe poświęcone zagadnieniu emigracji z Italii i karze wygnania, ale w nich przymusowa emigracja przedstawicieli obozów sullańskiego i mariańskiego w okresie pierwszej wojny domowej albo nie została omówiona (zob. G.P. Kelly, A History of Exile..., s. 3, 93-100), albo zostało to zrobione bardzo powierzchownie. Por. A.J.N. Wils on, Emigration from Italy in the Republican Age of Rome, New York 1966, s. 28, 46.

${ }^{6}$ Zob. np. B.A. Marsha11, Crassus: A Political Biography, Amsterdam 1976, s. 11-13; M. Labitzke, Marius. Der verleumdete Retter Roms, Münster 2013, s. 211-223. 
Wybuch pierwszej wojny domowej doprowadził do podziału rzymskiej sceny politycznej na dwa obozy. W pierwszym znaleźli się zwolennicy L. Korneliusza Sulli, drugi skupił się wokół konsula 87 roku L. Korneliusza Cynny i sześciokrotnego konsula G. Mariusza. Obie strony krwawo prześladowały wrogów. Instrumentem prawnym pozwalającym na represjonowanie nieprzyjaciół stała się hostis declaratio, a w późniejszym okresie, po przejęciu dyktatury przez Sullę w 82 roku, lex de proscribendis malis civibus, które wyjmowały spod prawa przeciwników politycznych. Osoby ogłoszone wrogami lub proskrybowane można było bezkarnie zabić, a ich majątki skonfiskować (za głowy proskrybowanych wyznaczano nawet nagrody) ${ }^{7}$. Jeśli więc taki obywatel chciał uniknąć śmierci, musiał opuścić Rzym i szukać azylu poza jego murami, a najlepiej poza Italią.

Hostis declaratio z 88 roku prawdopodobnie była pierwszą tego typu uchwałą przegłosowaną przez senat ${ }^{8}$. Na zaprezentowanej senatorom liście znalazły się nazwiska 12 czołowych przedstawicieli popularów, którzy mieli zostać wyjęci spod prawa. Po przyjęciu przez senat uchwały i zatwierdzeniu jej przez zgromadzenie ludowe stali się oni wrogami państwa. Pozbawiano ich tym samym prawa do procesu sądowego i odwołania się do ludu. Znanych jest 10 umieszczonych przez Sullę na liście nazwisk ${ }^{9}$. Byli to: sześciokrotny konsul G. Mariusz, jego syn Mariusz Młodszy, P. Sulpicjusz Rufus, P. Cetegus, D. Juniusz Brutus, Kw. Granniusz, Gn. Granniusz (brat Kwintusa, ale być może chodzi tutaj o Gn. Papiriusza Karbona ${ }^{10}$ ), P. Albinowanus, M. Letoriusz i Kw. Rubriusz Warron. Prawdopodobnie na liście znaleźli się także M. Mariusz, młodszy brat G. Mariusza, jego syn M. Mariusz Gratidianus lub G. Marcjusz Censorinus ${ }^{11}$. Uczonych dziwi fakt, że na liście nie znalazły się nazwiska innych znaczących przedstawicieli popularów (np. Kw. Sertoriusza) ${ }^{12}$. Stało się tak prawdopodobnie dlatego, że Sulla nie chciał uderzyć w cały obóz popularów, a jedynie w najbliższych współpracowników Mariusza i Sulpicjusza Rufusa. Innymi słowy wymienieni w uchwale hostes to przedstawiciele factio Mariusza z nim jako liderem oraz jego najbliżsi krewni, współpracownicy, oddani demagogowie i reprezentanci interesów ekwickich.

7 T.R.S. Broughton, The Magistrates of Roman Republic, vol. 2, New York 1952, s. 40, 46, 69 (źródła). Zob. także: A. Lintott, Violence..., s. 155; F. Hinard, Les proscriptions de la Rome républicaine, Paris-Roma 1985, s. 136; Ch. Me ier, Res publica amissa. Eine Studie zu Verfassung und Geschichte der späten römischen Republik, Wiesbaden 1966, s. 253-255.

${ }^{8}$ Podkreśla to R.A. B a uman, The Hostis Declarations of 88 and 87 B.C., „Athenaeum” 1973, vol. 51, fasc. 1-2, s. 270. O uchwale z 88 r. zob. Cic., Brut. 168; Liv., Per. 77; App., BC 1, 60, 271; Val. Max. 1, 5, 5, por. 3, 8, 5; Vell. 2, 19, 1; Flor. 2, 9, 8. Szerzej o niej: H. A p pe 1, Kontrowersje wokót senatus consultum ultimum. Studium z dziejów późnej republiki rzymskiej, Toruń 2013, s. 151-159. Tam dalsza literatura.

${ }^{9}$ App., BC 1, 60, 271. Identyfikuje ich B.R. Katz, The First Fruits of Sulla March, „L'Antiquité Classique" 1975 , t. 44, fasc. 1, s. 105-115.

10 Por. F. Münzer, Cn. Papirius (38) [w:] Realencyclopädie der classischen Altertumswissenschaft, Bd. 36, Stuttgart 1949, col. 1024; E. B a d i a n, Caepio and Norbanus: Notes on the Decade 100-90 B.C., „Historia” 1957, Bd. 6, H. 3, s. 344-345.

${ }^{11}$ Por. B.R. Katz, The First Fruits..., s. 112-114.

12 Ibidem, s. 106-107. 
Spośród 12 hostes aż 11 udało się uciec z Italii, tylko jeden - P. Sulpicjusz Rufus został wydany przez własnego niewolnika i zabity. Jego głowę odesłano do Sulli i wystawiono na forum na widok publiczny ${ }^{13}$. Wraz z 11 zbiegami najpewniej opuściła Italię jakaś grupa ich zwolenników, ale nie jestem w stanie nic powiedzieć o jej liczebności, gdyż - poza informacjami o zwolennikach Mariusza, którzy ruszyli za nim do Afryki ${ }^{14}$ - brak o tym wiadomości w źródłach. Z wyjątkiem Sulpicjusza Rufusa i Mariusza, wobec których osobista niechęć Sulli była największa ${ }^{15}$, uciekinierów nie ścigano chyba z wielką zapalczywością, skoro niemal wszystkim udało się wydostać z Italii. Z drugiej strony fakt, że zdecydowali się ją opuścić, świadczy o tym, iż odczuwali duże zagrożenie i obawiali się o swoje życie.

Najwięcej wiadomości zachowało się o ucieczce Mariusza ${ }^{16}$. Przetrwała dramatyczna, niemal romantyczna wersja przygód i cierpień, jakie sześciokrotny konsul musiał znosić w drodze na wygnanie. Wersja jest tak fantastyczna, a wypadki tak nieprawdopodobne, że część badaczy odrzuca przekaz, twierdząc, że Plutarch - bo to on jest głównym informatorem - specjalnie ubarwił historię przykrości doznawanych przez Mariusza, aby w ten sposób niejako wytłumaczyć jego późniejsze okrucieństwo wobec wrogów ${ }^{17}$. Mariusz, opuszczając Rzym, musiał się spieszyć, gdyż - zdaniem Plutarcha - natychmiast po ogłoszeniu go wrogiem ruszyła za nim pogoń. Teoretycznie mógł próbować chronić się przed siepaczami w trzech miejscach: w Italii (gdzie miał swoich zwolenników, np. w Etrurii1 ${ }^{18}$ ), w Hiszpanii (uchodzącej za bastion mariańczyków, gdzie sześciokrotny konsul cieszył się dużą popularnością, która wiązała się z jego namiestnictwem w Hiszpanii Dalszej w latach 114-113 ${ }^{19}$ ) lub w Afryce (gdzie przebywali jego weterani ${ }^{20}$ ). Wybór tego ostatniego miejsca z pewnością nie był przypadkowy: Mariusz miał tam duże możliwości rekrutacyjne, mógł więc zgromadzić wojsko i wykorzystać je w próbie powrotu do Italii. Można się zastanawiać, ilu spośród rekrutowanych było mieszkańcami prowincji, a ilu uciekinierami z Rzymu, którzy za Mariuszem przedostali się do Afryki, czy to w obawie o własne życie, czy też w ślad za swoim przywódcą. Appian wyraźnie pisze, że do

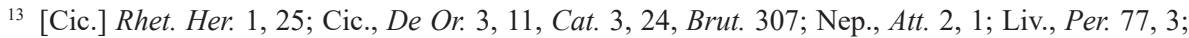
Vell. 2, 19, 1; Val. Max. 6, 5, 7; Plut., Sulla 10, 1; Flor. 2, 9, 8; App., BC 60, 272; Exsuper. 20; Oros. 5, 19, 6. R.A. B a uman, The Hostis Declarations..., s. 271.

${ }^{14}$ App., $B C$ 1, 67, 305.

${ }^{15}$ Niechęć między Sullą a Mariuszem rosła od czasów wojny jugurtyńskiej. Zob. np. Plut., Mar, 10.5. O relacjach Mariusza i Sulli patrz: E. Gabba, Mario e Silla [w:] ANRW, Bd. 1.1, Berlin-New York 1972, s. $764-805$.

${ }_{16}$ Plut., Mar. 35, 5 - 43, 3; App., BC 1,61 - 62. Szerzej na ten temat: T.F. Carn ey, The Flight and Exile of Marius, „Greece \& Rome” 1961, vol. 8, no. 2, s. 98-121.

17 A. Pas serin i, C. Mario come uomo politico, „Athenaeum” 1934, vol. 12, s. 371.

18 Wiązało się to oczywiście z poparciem, którego Mariusz udzielił reformie przyznającej Italikom obywatelstwo. Zob. F. S ant an ge 1o, Marius, London 2016, s. 88.

19 T.R.S. Broughto n, The Magistrates..., vol. 1, s. 534; R. Evan s, Gaius and Marcus Marius in Iberia and Gaul: Family Affairs and Provincial Clients, „Acta Classica” 2008, vol. 51, s. 77-90.

${ }^{20}$ T.F. Carn ey, A Biography of C. Marius, Chicago 1970, s. 58. 
Mariusza dotarli uciekinierzy z Italii2 ${ }^{21}$. Zapewne weszli oni w skład armii zwerbowanej przez Mariusza, którą ten poprowadził ze sobą do Italii zaraz po przejęciu przez Cynnę władzy w stolicy i uchwaleniu prawa o odwołaniu wygnańców ${ }^{22}$.

Perypetie pozostałych 10 uciekinierów, którym udało się opuścić Italię, znane są w znacznie mniejszym stopniu. Wiadomo, że nie wszyscy zbiegli do Afryki tam udali się Mariusz Młodszy, Cetegus, Granniusz, Albinowanus, Letoriusz i inni, których nazwisk Appian nie podaje ${ }^{23}$. Druga grupa uchodźców przedostała się do Hiszpanii, gdzie poprowadził ją Brutus, pretor 88 roku $^{24}$. Wybór miejsca w tym przypadku także był świadomy. Wspominałem już, że popularzy w Hiszpanii cieszyli się sporymi wpływami. Można przypuszczać, że uchodźcy z Brutusem na czele udali się do Hiszpanii Dalszej, prowincji, której zarząd sprawował niegdyś sławny D. Juniusz Brutus Kallaikus, i który na pewno związał ze swoim rodem tamtejszą elitę, dzięki czemu zbiegowie z Italii mogli znaleźć tam przychylne i bezpieczne przyjęcie ${ }^{25}$. Na temat pobytu Brutusa et consortes w Hiszpanii nie zachowały się żadne szczegóły, pewne jest tylko, że ich pobyt na Półwyspie Iberyjskim trwał krótko ${ }^{26}$.

W 87 roku sytuacja w państwie diametralnie się zmieniła. Na początku roku na wojnę z Mitrydatesem wyjechał Sulla, pozostawiając u władzy dwóch spierających się konsulów: optymatę Gn. Oktawiusza i sprzyjającego popularom L. Korneliusza Cynnę. Ten drugi umożliwił powrót wygnańcom, a następnie sprzymierzył się z Mariuszem, który na czele niewielkiej armii powrócił do Italii. Wspólnie z Cynną pokonali Gn. Oktawiusza i optymatów ${ }^{27}$. W konsekwencji w stolicy doszło do znacznie bardziej krwawych i zakrojonych na większą skalę represji niż te, które miały miejsce kilka miesięcy wcześniej ${ }^{28}$. Appian z Aleksandrii wymienia nazwiska pomordowanych. Byli to: M. Antoniusz, G. Cezar, L. Cezar, P. Krassus Starszy i Młodszy, Kw. Katulus, L. Merula, Bebiusz, Numitoriusz, Anchariusz, Serranus, Lentulus. Historyk ze zgrozą stwierdza, że głowy ofiar wystawiano na widok publiczny, a ciał nie pozwalano grzebać, przez co stawały się pożywką dla psów i ptaków ${ }^{29}$. Siepacze Mariusza byli bezlitośni, a pogoń za uciekinierami tym razem okazała się bardzo skuteczna. Według Appiana zbiec udało się tylko jednemu spośród uciekinierów M. Cecyliuszowi Kornutusowi, uratowanemu przez niewolników, którzy upozorowali

${ }^{21}$ App., $B C 1,62,280 ; 67,305$. Wątpliwe, by było ich wielu, gdyż popularzy w Rzymie w trakcie nieobecności Mariusza wciąż byli politycznie bardzo aktywni. Zob. M. Lovano, The Age of Cinna: Crucible of Late Republican Rome, Stuttgart 2002, s. 32-39.

${ }_{22}$ Plut., Mar. 41, 2; App., BC 1, 67, 304.

${ }^{23}$ App., $B C$ 1, 62, 280.

24 T.R.S. Broughto n, The Magistrates..., vol. 2, s. 40.

${ }^{25}$ Ibidem, vol. 1, s. 485.

${ }^{26}$ Gran. Lic. 35, 7-8. A.J.N. Wils o n, Emigration from Italy, s. 29.

${ }^{27}$ M. L ovan o, The Age of Cinna, s. 32-41; A. Ziółk o w s ki, Historia Rzymu, Poznań 2004, s. 331.

${ }^{28}$ Cass. Dio 30-35, 102, 8; 10-11; Flor. 2, 9, 13-17; Vell. 2, 22, 1-5; Oros. 5, 19, 20-23; Liv., Per. 80; Diod. 38/39, 6; Plut., Mar. 43, 5-9, 44, 9; Sert. 5, 4-5. Rozmiary masakry z pewnością zostały w źródłach wyolbrzymione, wątpliwości badaczy dotyczą stopnia przekłamań. Zob. M. L o v a n o, The Age of Cinna, s. 45 , przyp. 71 , gdzie dalsza literatura.

${ }_{29}$ App., BC 1, 72, 332-335. Zob. T.R.S. Broughton, The Magistrates..., vol. 2, s. 46 (źródła); M. L ov a o, The Age of Cinna, s. 45-50. 
śmierć swego pana i oszukali w ten sposób napastników ${ }^{30}$. Ocalony Kornutus udał się następnie do Galii, gdzie prawdopodobnie dołączył do jej namiestnika, sullańczyka G. Waleriusza Flakkusa, ale żadnych szczegółów o jego ucieczce ani o pobycie w prowincji nie znamy.

Appian nie ma jednak racji, twierdząc, że Kornutus był jedynym ocalałym przed represjami - uciekinierów z pewnością było więcej. Niektórzy z nich po wydostaniu się z Italii udali się do Sulli na Wschód, inni rozpierzchli się po różnych częściach imperium. Dowodzą tego przekazy innych autorów antycznych. Czytamy w nich, że wielu przeciwników politycznych Cynny i Mariusza w obawie przed represjami decydowało się na ucieczkę z Rzymu, tym samym stawali się więc uchodźcami. Zachowane na ten temat dane są wszak nad wyraz ogólne. Plutarch podaje na przykład, że „w Rzymie Cynna i Karbon stosowali wobec najznakomitszych osobistości bezprawie i gwałt. Tłumy uciekających przed ich tyranią chroniły się do obozu Sulli niby do bezpiecznej przystani i w krótkim czasie powstał wokół niego rodzaj senatu. Nawet Metella, która wraz z dziećmi z trudem uszła przed niebezpieczeństwem, przybyła do niego, przynosząc wiadomość, że dom jego i dobra zostały przez nieprzyjaciela spalone, i prosiła go, by szedł na ratunek ojczyźnie"31. Wellejusz Paterkulus z kolei pisze, że „W okresie panowania Cynny nad Italią większa część arystokracji (maior pars nobilitatis) rządowej szukała schronienia u Sulli najpierw w Achai, potem w Azji" 32 . Według Eutropiusza „Pozostała część senatorów po gromadnej ucieczce z Miasta przybyła do Grecji, prosząc Sullę, by przyszedł ojczyźnie z pomocą" ${ }^{\text {33 }}$. Z kolei Orozjusz relacjonuje: „W tym samym czasie senatorowie, którzy zostali żywi, ponieważ uciekając z miasta ocalili swoje życie przed gwałtami Cynny, okrucieństwem Mariusza, szaleństwem Fimbrii i bezczelnością Sertoriusza, wyruszyli do Grecji i zmusili prośbami Sullę do przyjścia z pomocą ojczyźnie będącej w niebezpieczeństwie lub, ściślej mówiąc, ojczyźnie prawie już straconej" 34 .

W zacytowanych relacjach brakuje konkretnego wskazania nazwisk uciekinierów, niemniej wszyscy autorzy zaprezentowanych relacji są zgodni, że skala exodusu z Rzymu była ogromna. Podkreślają, że przed represjami uciekło wielu członków senatu - ich liczba była na tyle duża, że sformowali pierwszy dziejach Rzymu ,senat na wygnaniu"35. Być może spełniał on funkcję doradczą u boku Sulli, ale wydaje się, że dla prokonsula tak naprawdę ważniejszy był wydźwięk propagandowy i legitymizujący owego senatu - warto bowiem wspomnieć, że władza cynnańska w Rzymie wykonała względem niego dokładnie ten sam manewr, który on zastosował w 88 roku wobec swoich przeciwników, i ogłosiła go wrogiem publicznym ${ }^{36}$.

${ }^{30}$ App., BC 1, 73, 336; Plut., Mar. 43, 6. F. Münzer, M. Caecilius Cornutus [w:] Realencyclopädie der classischen Altertumswissenschaft, Bd. 3.1, Stuttgart 1897, col. 1200.

31 Plut., Sulla 22,1 (tłum. M. Brożek).

32 Vell. 2, 23, 3 (tłum. E. Zwolski).

33 Eutrop. 5, 7, 3 (tłum. P. Nehring, B. Bibik).

34 Oros. 5, 20, 1 (tłum. H. Pietruszczak).

35 E. Gabba, Senati in esilio [w:] idem, Esercito e societá nella trada repubblica romana, Firenze 1973, s. 430.

36 App., BC 1, 73, 340; Mith. 204. H. Appel, Kontrowersje..., s. 158. 
Sulla chętnie przyjmował więc w swe szeregi uchodźców z Rzymu, a każdy przybyły do niego senator wzmacniał jego pozycję w ewentualnych negocjacjach z senatem w sprawie powrotu do Italii i potencjalnego kompromisu z cynnańczykami.

Znanych jest wiele nazwisk sojuszników Sulli towarzyszących mu na Wschodzie - najwięcej należy do senatorów - nie tak łatwo jednak oddzielić tych, którzy w 87 roku wyruszyli z nim na wojnę z Mitrydatesem, od tych, którzy dołączyli do niego po ucieczce z Italii przed prześladowaniami Mariusza i Cynny. Niemniej kilku spośród najwybitniejszych uchodźców, którzy - jak się wydaje - przedostali się do Sulli na skutek grożących im represji lub wręcz uciekając przed owymi represjami, jesteśmy w stanie zidentyfikować.

Wśród uciekinierów z Rzymu znalazł się prawdopodobnie App. Klaudiusz Pulcher, pretor z 89 roku, który zastąpił Sullę w oblężeniu Noli po tym, jak ten wyjechał na wojnę z Mitrydatesem. Wiadomo, że Pulcher był przeciwnikiem politycznym Cynny, a ponieważ został pominięty w cenzusie z 86 roku, można dowodzić, iż opuścił Italię i dołączył do Sulli na Wschodzie ${ }^{37}$. Podobnie uczynił zapewne M. Antoniusz (który otrzymał później przydomek Creticus), syn zamordowanego konsulara. Co prawda Ernst Badian próbował udowodnić, że Antoniusz pozostał w Rzymie i jakimś cudem uniknął represji ${ }^{38}$, ale to wątpliwe. Potomkowie zamordowanych konsularów nawet po pierwszej fali prześladowań nie mogli czuć się bezpiecznie w Italii , co potwierdza ucieczka Krassusa do Hiszpanii. Trudno także zgodzić się z argumentem, że wokół Sulli gromadzili się jedynie ludzie, których mógł wykorzystać podczas przyszłej walki zbrojnej o władzę w Rzymie ${ }^{39}$. Przeciwnie - jak już wyżej wspominałem, nie ma wątpliwości, że każdy uchodźca ze stolicy o znaczących wpływach politycznych był dla Sulli ważny również ze względów propagandowych.

Istnieją także poważne przesłanki, by przypuszczać, że pośród nobilów, którzy przedostali się do Sulli na Wschód na skutek represji grożących im w Rzymie, znaleźli się - oprócz Antoniusza i App. Klaudiusza - Kw. Lutacjusz Katulus ${ }^{40}$, Gn. Oktawiusz i L. Oktawiusz (syn lub brat zamordowanego konsula) ${ }^{41}$, P. Serwiusz Watia Isauricus $^{42}$ i P. Lentulus Sura ${ }^{43}$. Szeregi przyszłego dyktatora zasiliło zapewne jeszcze wielu innych, mniej znaczących senatorów, których musiało wszak być sporo, skoro byli w stanie utworzyć wspomniany wcześniej, obradujący przy prokonsulu ,senat na wygnaniu".

Wśród uchodźców z Italii szczególną uwagę zwraca wspomniana już żona Sulli, Metella, która wraz z jego dziećmi przedostała się do Grecji. Niektórzy badacze

37 E.S. Gruen, Roman Politics and the Criminal Courts, 149-78 B.C., Cambridge 1968, s. 237; A. Ke a ve ney, Who Were the Sullani?, „Klio” 1984, vol. 66, s. 118.

${ }^{38}$ E. B a di a n, Waiting for Sulla, „The Journal of Roman Studies” 1962, vol. 52, no. 1-2, s. 52. Por. A. Keaveney, Who Were the Sullani?, s. 126-127.

39 E. B adian, Waiting for Sulla, s. 52-53.

${ }^{40}$ A. Ke aven ey, Who Were the Sullani?, s. 127-128.

${ }^{41}$ Ibidem, s. 128.

42 Ibidem.

${ }^{43}$ Ibidem. 
sądzą, że Cynna pozwolił jej bezpiecznie udać się do męża44, ale Appian wyraźnie zaznacza, że była poszukiwana, a skoro tak, to można założyć, że gdzieś poza Rzymem ukrywała się przed prześladowaniami ${ }^{45}$. Ostatecznie - jak podkreśla Plutarch - z trudem udało jej się ujść z Italiii ${ }^{46}$. Casus Metelli rodzi kolejne pytanie: czy z Italii uciekały również rodziny innych prominentnych polityków wrogich obozowi cynno-mariańskiemu, którzy przebywali na Wschodzie lub w innych częściach imperium? Nie można tego wykluczyć, choć hipoteza, że do Sulli dotarła również Julia, matka późniejszego triumwira M. Antoniusza, ma dość słabe podstawy ${ }^{47}$.

Uchodźcy przed represjami ze strony Mariusza i Cynny kierowali swe kroki głównie na Wschód do Sulli i robili to - jak się wydaje - z dwóch kluczowych powodów. Po pierwsze, u boku prokonsula mogli czuć się stosunkowo bezpiecznie. Nie groziło im wydanie przez nieżyczliwych lub żądnych nagrody ludzi, nie musieli się więc ukrywać i drżeć o życie. Po drugie, w Sulli widzieli wodza, u boku którego będą mogli powrócić do Italii oraz odzyskać utracone majątki i dawną pozycję.

Nie wszyscy uchodźcy przed prześladowaniami mariańsko-cynnańskimi szukali jednak schronienia na Wschodzie. Co najmniej dwóch przedstawicieli wybitnych rodów arystokratycznych, którzy w przyszłości odegrają w obozie sullańskim kluczową rolę, uciekło w inne części imperium - do Hiszpanii i Afryki. Pierwszy ze wspomnianych uciekinierów to M. Licyniusz Krassus, który w obawie o życie w popłochu opuścił Italię. Dokładną relację zawdzięczamy Plutarchowi ${ }^{48}$. Wspominałem już, że wśród ofiar represji politycznych w 87 roku znaleźli się ojciec i starszy brat Krassusa. Sam Krassus został oszczędzony - rzekomo z powodu młodego wieku, co nie może być prawdą, miał już bowiem w tym czasie 28 lat ${ }^{49}$. Zdecydował się jednak uciec z Rzymu w towarzystwie trzech przyjaciół i dziesięciu niewolników. Kim byli owi przyjaciele - nie wiadomo. Być może po prostu towarzyszyli Krassusowi, ale niewykluczone, że również opuszczali Italię w obawie o życie. Grupka udała się zatem do Hiszpanii, w której Krassus u boku ojca w latach 96-93 zdobywał szlify wojenne, wchodząc być może w skład sztabu ojca (jako contubernalis); wtedy również zawiązał w Hiszpanii przyjaźnie, które tak bardzo przydały mu się po 87 roku. Krassus jako uchodźca przebywał w Hiszpanii przez trzy lata, przy tym przez pierwsze osiem miesięcy swego pobytu pozostawał w ukryciu, z którego wyszedł dopiero, kiedy do Hiszpanii dotarła wieść o śmierci Mariusza. Z kolei po otrzymaniu wiadomości o śmierci Cynny Krassus przystąpił do zbierania wojska i łupienia okolicznych, zapewne sprzyjających mariańczykom miast. W Hiszpanii pomagali mu klienci Licyniuszy, między innymi niejaki Pakcjanus, osiadły tam Italik, jeden z tak zwanych Hispanienses. Dzięki jego pomocy Krassusowi udało się ostatecznie zebrać

${ }^{44}$ H. B en net, Cinna and His Times: A Critical and Interpretative Study of Roman History during the Period 87-84 B.C., Menasha 1923, s. 29-30.

45 App., $B C$ 1, 73, 340.

${ }^{46}$ Plut., Sulla 22, 2.

${ }^{47}$ A. Ke aveney, Who Were the Sullani?, s. 126-127.

${ }^{48}$ Plut., Crass. 4, 1-6, 1.

${ }^{49}$ Por. Plut., Crass. 17, 3. M. Gelzer, M. Licinius Crassus Dives [w:] Realencyclopädie der classischen Altertumswissenschaft, Bd. 13.1, Stuttgart 1926, col. 295. 
dwuipółtysięczną armię, którą w 83 roku poprowadził do przebywającego wówczas w Grecji Sulli ${ }^{50}$.

Inna była sytuacja Metellusa Piusa, stojącego wówczas na czele potężnej factio Caecilii Metelli ${ }^{51}$. Od początku lat 80 . pozostawała ona w bliskich relacjach z Sullą. Co prawda Metellus zapewne nie pochwalał przeprowadzonego przez Sullę zamachu stanu, niemniej nie poparł też Cynny i Mariusza w 87 roku. Po ich dojściu do władzy najwidoczniej nie czuł się w Italii bezpieczny i wycofał się do Afryki. Nie uciekał jednak z Italii, jak wcześniej Mariusz czy Krassus, nikt go też nie ścigał. Jego sytuacja była więc wyjątkowa. W 87 roku nie był wyjęty spod prawa, dysponował własną siłą zbrojną i nie opowiedział się otwarcie po stronie Sulli. Pozostawał jednak poza Italią, do której nie mógł bez obawy wrócić, można go więc traktować jako uchodźcę politycznego.

W jego przypadku wybór miejsca schronienia był jasny - Afryka to teren, na którym Metellusowie posiadali wielu klientów, co spowodowało, że został tam przyjęty życzliwie. Dopiero w 84 roku cynnańczycy wysłali pretora G. Fabiusza Hadriana, aby wydrzeć prowincję z rąk Metellusa ${ }^{52}$. Fakt, że stało się to tak późno, można tłumaczyć na różne sposoby. Możliwe, że dopiero wówczas zaczęli dostrzegać niebezpieczeństwo z jego strony. Cynnańczycy w Rzymie szykowali się wszak na wojnę z Sullą i z pewnością nie chcieli za plecami zostawiać sobie potencjalnego wroga. Niewykluczone jednak, że wpływ na wysłanie Hadriana do Afryki miało fiasko porozumienia z Sullą, do którego senat próbował doprowadzić w 84 roku, i Metellus - zapewne zwolennik takiego porozumienia - być może dopiero wówczas zdecydowanie opowiedział się po stronie Sulli, przełamując swą dotychczasową neutralność.

Zwycięstwo L. Korneliusza Sulli w wojnie domowej w Italii w latach 83-82 otworzyło drogę do nowych represji wymierzonych w przeciwników politycznych. Ich rozmiar osiągnął niespotykaną dotąd skalę. Na listach proskrypcyjnych umieszczane były nazwiska rzeczywistych i domniemanych wrogów Sulli, który wymusił mianowanie go dyktatorem i przejął nieograniczoną władzę w Rzymie ${ }^{53}$. Odbywająca się w stolicy rzeź zmusiła wielu obywateli do szukania ocalenia w ucieczce z Italii. Sulla nie chciał dopuścić do zorganizowania się skupisk uchodźców poza Italią i konsekwentnie kazał je rozbijaćs

${ }^{50}$ Na temat pobytu M. Licyniusza Krassusa w Hiszpanii patrz: T. Ła d oń, Hiszpania jako miejsce..., s. $218-223$.

${ }^{51}$ J. van Ooteghem, Les Caecilii Metelli de la république, Bruxelles 1967, s. 179; T. Ła doń, Caecilii Metelli a Sulla. Sojusznicy czy rywale?, „Roczniki Humanistyczne” 2018, t. 66, nr 3, s. 193.

${ }^{52}$ Liv., Per., 84.

${ }_{53}$ T.R.S. Broughton, The Magistrates..., vol. 2, s. 66-67, 74-76; C. Lanzani, Lucio Cornelio Silla dittatore. Storia di Rome negli anni 82-78 A.C, Milano 1936, s. 5-25, 93-121; Ch. Meier, Res publica amissa, s. 253-255; F. Hinard, Les proscriptions..., s. 17-257; F. Hurlet, La dictature de Sylla : monarchie ou magistrature républicaine? Essai d'histoire constitutionnelle, Bruxelles-Rome 1993.

${ }^{54}$ Korzystał przy tym m.in. z pomocy Pompejusza, którego działania cechowało tak wielkie okrucieństwo wobec wrogów, że nadano mu przydomek Adulescentulus Carnifex. T.R.S. Broughton, The Magistrates..., vol. 2, s. 70, 77 (źródła). Szerzej: M. Gelzer, Pompeius, München 1949, s. 40 i n.; 
Najwięcej uciekinierów przed represjami sullańskimi znalazło schronienie w Hiszpanii. Stało się tak z kilku powodów. Najważniejszym były wspomniane już popularskie sympatie - zwłaszcza nazwisko Mariusza cieszyło się wśród mieszkańców prowincji dużą popularnością. Wydaje się także, że już w 83 roku liderzy mariańscy uznawali prowincje hiszpańskie za miejsce azylu na wypadek niepowodzenia w wojnie z Sullą5. W celu przygotowania owego azylu do Hiszpanii w randze prokonsula obydwóch prowincji wyekspediowany został Kw. Sertoriusz ${ }^{56}$. Udało mu się zorganizować bazę oporu, do której zaczęli przybywać uciekinierzy przed represjami sullańskimi, oraz zdobyć sympatię miejscowych plemion ${ }^{57}$. I choć Sertoriusz w 81 roku na krótko został wyparty z Hiszpanii przez sullańczyka, G. Anniusza, to powrócił do niej w 80 roku, a poczynione wcześniej kroki pozwoliły mu stworzyć tam ośrodek, do którego zdążać będą wszyscy przeciwnicy reżimu sullańskiego. Ich siła okazała się tak wielka, że zdołali zorganizować senat opozycyjny wobec obradującego w Rzymie ${ }^{58}$.

$\mathrm{Na}$ podstawie poczynionych rozważań wyraźnie widać, że przez całe lata 80 . I wieku nieustająco trwał proceder uchodźstwa politycznego z Rzymu. Najważniejszą i najbardziej rozpoznawalną część uchodźców politycznych stanowili czołowi przedstawiciele arystokracji senatorskiej, niezależnie od tego, czy uciekali przed prześladowaniami ze strony Sulli czy Mariusza. Trzeba jednak wyraźnie podkreślić, że wśród uchodźców z Italii znajdowały się nie tylko osoby oficjalnie prześladowane przez państwo, czyli ogłoszone wrogami publicznymi lub proskrybowane. Niewątpliwie Rzym opuszczało znacznie więcej obywateli - czynili tak, gdy tylko uznali, że grozi im niebezpieczeństwo ze strony władz. W atmosferze mordów, proskrypcji i wzajemnej podejrzliwości ucieczki z Italii stały się zjawiskiem powszechnym. Często na exodus z Rzymu decydowali się także klienci swych wyjętych już wcześniej spod prawa patronów (czy też przywódców factio), przebywających poza Italią. Udawali się bezpośrednio do nich (w źródłach odnotowany jest napływ ludzi do Mariusza i Sulli, w czasie gdy byli oni uchodźcami) w celu schronienia się u ich boku lub wspierania ich w powrocie do ojczyzny. Nie można wykluczyć, że niektórzy uchodźcy z Italii szukali schronienia w różnych częściach imperium w oczekiwaniu

J. van Ooteghem, Pompée le Grand, Namur 1954, s. 59-60; L. A mela Valverde, Cneo Pompeyo Magno. El defensor de la República romana, Madrid 2003, s. 51 i n.

${ }_{55}$ Plut., Sert. 6, 2; Exsuper. 8. K.G. Rijkhoek, Studien zu Sertorius 123-83 v. Chr., Bonn 1992, s. $178-187$.

${ }^{56}$ E. B a di a n, Waiting for Sulla, s. 59; C.F. Ko n r a d, Plutarch's Sertorius: A Historical Commentary, Chapel Hill-London 1994, s. 88. Przyznana Sertoriuszowi ranga prokonsula została potwierdzona dzięki napisom umieszczonym na odnalezionych $\mathrm{w}$ trakcie prac archeologicznych pociskach do procy. Zob. G. Chic García, Sertorius, proconsul [w:] Epigrafia Hispánica de época republicana, Zaragoza 1986, s. $171-176$.

${ }^{57}$ Plut., Sert. 6, 4. C.F. Kon ra d, Plutarch's Sertorius, s. 98.

58 A.J.N. Wils o n, Emigration from Italy, s. 29 i n.; P.O. S p a n n, Quintus Sertorius and the Legacy of Sulla, Fayeteville 1987, s. 169-174; T. Ła d oń, Sertoriański senat jako ikona opozycji antysullańskiej w latach siedemdziesiatych I wieku przed Chrystusem [w:] W kręgu ikon wladzy, ludzi oraz idei świata starożytnego, red. A.A. Kluczek, N. Rogosz, A. Bartnik, Katowice 2014, s. 57-70. 
na zmianę koniunktury politycznej ${ }^{59}$. Uchodźcami stawali się również obywatele pozostający poza granicami Italii w trakcie zmian władzy w Rzymie - tak było w przypadku Sertoriusza, który szybko został proskrybowany ${ }^{60}$. Przeciwnicy rządzących nie mogli wszak powrócić do Rzymu ze względu na grożące im represje polityczne.

Kierunki ucieczki podejmowane przez uchodźców opuszczających Italię były różne i zależały od indywidualnych decyzji uciekinierów. Osoby posiadające koneksje w prowincjach szukały schronienia u swoich klientów, kierowały więc kroki do Afryki, Hiszpanii, Galii czy prowincji wschodnich. Najwięcej uchodźców uciekało jednak do osób, które uważali za swoich przywódców (stąd np. exodus do przebywającego na Wschodzie Sulli). W okresie dyktatury sullańskiej głównym ośrodkiem, w którym chronili się przeciwnicy dyktatora, stały się prowincje hiszpańskie pod zarządem Kw. Sertoriusza, gdyż silne były tam wpływy mariańskie, a ponadto namiestnik ów dysponował poparciem miejscowych ludów i znaczną armią.

Wobec braku danych w źródłach nie ma możliwości ustalenia liczby uchodźców czy ich składu społecznego. Wynika to między innymi z faktu, że autorzy antyczni koncentrowali swą uwagę na działaniach najważniejszych osób w państwie, szczegółowo opisali więc na przykład ucieczkę wyjętego spod prawa Mariusza do Afryki, zaś o 11 represjonowanych przez Sullę wraz z nim czołowych mariańczykach wspomnieli tylko na marginesie prowadzonych rozważań. Podobnie perypetie M. Krassusa, który uszedł przed prześladowaniami do Hiszpanii, znane są dlatego, że w późniejszym okresie będzie jedną z najbardziej wpływowych osób w państwie i osobny żywot poświęcił mu Plutarch. Tysiące anonimowych uciekinierów z Italii, którzy chronili się w prowincjach przed represjami czy to ze strony władz cynno-mariańskich, czy to ze strony Sulli, mogło powrócić do Rzymu dopiero po ustabilizowaniu się sytuacji wewnętrznej w państwie.

W latach 80. następowała eskalacja przemocy w Rzymie - wyrazem tego była coraz większa liczba ofiar śmiertelnych - co zwiększało skalę uchodźstwa. Autorzy źródeł odnotowują jednego zabitego i kilkunastu uchodźców w trakcie pierwszych prześladowań sullańskich w 88 roku, po represjach mariańskich w 87 roku znamy nazwiska kilkunastu zabitych i posiadamy informacje (zapewne przesadzone) o wielu morderstwach z powodów politycznych, czego wynikiem była również odnotowana znacznie większa liczba uciekinierów. $Z$ kolei autorzy antyczni podają, że po zwycięstwie Sulli w 82 roku pomordowanych w wyniku proskrypcji były tysiące obywateli, a uciekinierów z Italii obliczają na dziesiątki tysięcy, jeśli wliczyć w tę liczbę lepidańczyków, którzy w latach 70. przedostali się do Hiszpanii po klęsce buntu M. Emiliusza Lepidusa w 77 roku. Wszyscy ci uchodźcy mieli zakaz powrotu do Italii czy to jako proskrybowani, jak w przypadku Sertoriusza i uciekinierów z końca lat 80., czy jako hostes publici, jak było to w przypadku lepidańczyków ${ }^{61}$.

Na koniec warto zaznaczyć, że uchodźcy polityczni z Rzymu postrzegali swoją sytuację, czyli pozostawanie poza Italią, jako tymczasową. Czekali czy to na zmianę

${ }^{59}$ Prawdopodobnie takie motywy kierowały poczynaniami m.in. M. Licyniusza Krassua i Kw. Cecyliusza Metellusa Piusa.

${ }^{60}$ Oros. 5, 21, 3. Por. Liv., Per. 90; Val. Max. 7, 3, 6; Flor. 2, 10, 2; Schol. Gronov. 317, 6 Stangl.

${ }^{61}$ C.F. Konrad, Metellus and the Head of Sertorius, „Gerión” 1988, vol. 6, s. 255-258. 
koniunktury politycznej w państwie, która pozwoli im na bezpieczny powrót, czy to - tak jak to było z uciekinierami na Wschód - traktowali Sullę jako swego lidera, u boku którego powrócą do Italii. Dopiero zwycięstwo w wojnie sertoriańskiej pozwoliło sullańczykom dokonać aktu amnestii i wyrazić zgodę na powrót uchodźców do Italii. Nie była to jednak amnestia całkowita - nie zostali nią bowiem objęci sertorianie $^{62}$, którzy pod koniec lat 80 . wyruszyli do Hiszpanii i nawet po wojnie sertoriańskiej musieli tam pozostać co najmniej przez kolejne 20 lat, gdyż proskrybowani $\mathrm{i}$ ich potomkowie mogli powrócić do Italii dopiero w $49 \mathrm{roku}^{63}$.

\section{BIBLIOGRAFIA}

\section{Źródła}

App., BC - Appianus, Bella civilia

App., Mith.-Appianus, Mithridateios

Cass. Dio-Cassius Dio Cocceianus

[Cic.] Rhet. Her. - [Cicero], Rhetorica ad Herennium

Cic., Brut. - Cicero, Brutus

Cic., Cat. - Cicero, In Catilinian orationes

Cic., De Or. - Cicero, De Oratore

Diod. - Diodorus Siculus

Eutrop. - Eutropius

Exsuper.-Julius Exsuperantius

Flor.-Lucius Anneus Florus

Gran. Lic.-Granius Licinianus

Liv., Per. - Titus Livius, Periochae

Nep., Att. - Cornelius Nepos, Atticus

Oros. - Paulus Orosius

Plut., Crass. - Plutarchus, Crassus

Plut., Mar. - Plutarchus, Marius

Plut., Sert. - Plutarchus, Sertorius

Plut., Sulla-Plutarchus, Sulla

Schol. Gronov. - scholia in Ciceronis orationes Lugdunensia sive Gronoviana (ed. Stangl)

Val. Max. - Valerius Maximus

Vell. - Velleius Paterculus

\footnotetext{
${ }^{62}$ Amnestia dokonana została na podstawie lex Plotia (Plautia) de reditu Lepidanorum. Ustawa ta objęła jednak najpewniej jedynie lepidańczyków, wyłączeni zaś niej zostali sertorianie. Zob. C.F. Konrad, Metellus..., s. 257. Por. N. Rogosz, Polityczna rola trybunatu ludowego w Rzymie $w$ latach restauracji sullańskiej, Katowice 1992, s. 114. Ustawa najczęściej datowana była na rok 70, czasami jednak jej datację przesuwa się o kilka lat wstecz, na rok 73, a nawet 74. Zob. F. García Morá, Lex Plautia de reditu Lepidanorum, „Florentia Iuberritana” 1992, vol. 3, s. 211-231.

${ }^{63}$ V. Vedaldi Ias bez, I figli dei proscritti sillani, „Labeo” 1982, vol. 27, s. 163-213.
} 


\section{Opracowania}

A mela Valverde L., Cneo Pompeyo Magno. El defensor de la República romana, Madrid 2003.

A p p el H., Kontrowersje wokót senatus consultum ultimum. Studium z dziejów późnej republiki rzymskiej, Toruń 2013.

Badian E., Caepio and Norbanus: Notes on the Decade 100-90 B.C., „Historia” 1957, Bd. 6, H. 3, s. 318-346.

B a di an E., Lucius Sulla: The Deadly Reformer, Sydney 1970.

B a di a n E., Waiting for Sulla, „The Journal of Roman Studies” 1962, vol. 52, no. 1-2, s. 4761.

Barden Dowling M., The Clemency of Sulla, „Historia” 2000, Bd. 49, H. 3, s. 303-340.

B a um a R.A., The Hostis Declarations of 88 and 87 B.C., „Athenaeum” 1973, vol. 51, fasc. 1-2, s. 270-293.

Bennet H., Cinna and His Times: A Critical and Interpretative Study of Roman History During the Period 87-84 B.C., Menasha 1923.

B roughton T.R.S., The Magistrates of Roman Republic, vol. 1-2, New York 1951-1952.

Carn ey T.F., A Biography of C. Marius, Chicago 1970.

Carney T.F., The Flight and Exile of Marius, „Greece \& Rome” 1961, vol. 8, no. 2, s. 98121.

Chic García G., Sertorius, proconsul [w:] Epigrafía Hispánica de época republicana, Zaragoza 1986, s. 171-176.

Evans R., Gaius and Marcus Marius in Iberia and Gaul: Family Affairs and Provincial Clients, „Acta Classica” 2008, vol. 51, s. 77-90.

Gabba E., Appiani Bellorum Civilium liber primus, Firenze 1958.

Gabba E., Mario e Silla [w:] ANRW, Bd. 1.1, Berlin-New York 1972, s. 764-805.

Gabba E., Senati in esilio [w:] E. G a b b a, Esercito e societá nella trada repubblica romana, Firenze 1973, s. 427-441.

García Morá F., Lex Plautia de reditu Lepidanorum, „Florentia Iuberritana” 1992, vol. 3, s. 211-231.

Gelzer M., M. Licinius Crassus Dives [w:] Realencyclopädie der classischen Altertumswissenschaft, Bd. 13.1, Stuttgart 1926, col. 295.

Gelzer M., Pompeius, München 1949.

Gruen E.S., Roman Politics and the Criminal Courts, 149-78 B.C., Cambridge 1968.

Gruen E.S., The Last Generation of the Roman Republic, Berkeley-Los Angeles-London 1974.

Hin ard F., Les proscriptions de la Rome républicaine, Paris-Roma 1985.

Hurlet F., La dictature de Sylla : monarchie ou magistrature républicaine? Essai d'histoire constitutionnelle, Bruxelles-Rome 1993.

Katz B.R., The First Fruits of Sulla March, „L'Antiquité Classique” 1975, t. 44, fasc. 1, s. $100-125$.

Keaveney A., Who Were the Sullani?, „Klio” 1984, vol. 66, s. 114-150.

Kelly G.P., A History of Exile in the Roman Republic, Cambridge 2006.

Kon rad C.F., Metellus and the Head of Sertorius, „Gerión” 1988, vol. 6, s. 253-261.

Kon rad C.F., Plutarch's Sertorius: A Historical Commentary, Chapel Hill-London 1994.

L a bitzke M., Marius. Der verleumdete Retter Roms, Münster 2013.

Lanzani C., Lucio Cornelio Silla dittatore. Storia di Rome negli anni 82-78 A.C., Milano 1936. 
Lintott A., Violence in Republican Rome, Oxford 1968.

Lovano M., The Age Of Cinna: Crucible of Late Republican Rome, Stuttgart 2002.

Ładoń T., Caecilii Metelli a Sulla. Sojusznicy czy rywale?, „Roczniki Humanistyczne” 2018, t. 66, nr 3, s. 189-205.

Ła d on T., Hiszpania jako miejsce schronienia opozycji w okresie pierwszej wojny domowej i dyktatury Lucjusza Korneliusza Sulli (88-79 p.n.e.) [w:] Rzym a Pótwysep Iberyjski. Różnorodność relacji od starożytności po współczesność, red. A. Grzelak-Krzy mianow s ka, M.J. Woźni a k, Łódź 2019, s. 213-232.

Ła doń T., Sertoriański senat jako ikona opozycji antysullańskiej w latach siedemdziesiatych I wieku przed Chrystusem [w:] W kregu ikon władzy, ludzi oraz idei świata starożytnego, red. A.A. Kluczek, N. Rog os z, A. B artnik, Katowice 2014, s. 57-70.

Mars hall B.A., Crassus: A Political Biography, Amsterdam 1976.

Me i r Ch., Res publica amissa. Eine Studie zu Verfassung und Geschichte der späten römischen Republik, Wiesbaden 1966.

Münze r F., Cn. Papirius (38) [w:] Realencyclopädie der classischen Altertumswissenschaft, Bd. 36, Stuttgart 1949, col. 1024.

Münzer F., M. Caecilius Cornutus [w:] Realencyclopädie der classischen Altertumswissenschaft, Bd. 3.1, Stuttgart 1897, col. 1200.

O oteg he m J. van, Les Caecilii Metelli de la république, Bruxelles 1967.

O ot e g h e m J. van, Pompée le Grand, Namur 1954.

P a s s erini A., C. Mario come uomo politico, „Athenaeum” 1934, vol. 12, s. 10-44.

Peter H., Die Quellen Plutarchs in den Biographieen der Römer, Halle 1865.

R a mage E.S., Sulla's Propaganda, „Klio” 1991, Bd. 73, s. 93-121.

Rijkhoek K.G., Studien zu Sertorius 123-83 v. Chr., Bonn 1992.

Rogos z N., Polityczna rola trybunatu ludowego w Rzymie w latach restauracji sullańskiej, Katowice 1992.

S ant angelo F., Marius, London 2016.

Sh erw in - W hite A.N., Violence in Roman Politics, „The Journal of Roman Studies” 1956, vol. 46, s. 1-9.

S pann P.O., Quintus Sertorius and the Legacy of Sulla, Fayeteville 1987.

Ve daldi I a sbe z V., I figli dei proscritti sillani, „Labeo” 1982, vol. 27, s. 163-213.

Wils o n A.J.N., Emigration from Italy in the Republican Age of Rome, New York 1966.

Ziółkow ski A., Historia Rzymu, Poznań 2004. 
